\title{
Distribution of milk flow in Holstein Friesian and Fleckvieh cows in Croatia
}

\begin{abstract}
Summary
The aim was to investigate the distribution of milk flow rate in Holstein Friesian and Fleckvieh cattle. Researches were made in four farms in Eastern Croatia with 534 cows. 2594 tests were made with computer milking equipment, Alfa-Laval and with digital milk flow counter made by Tru-Test Company. The measuring of milk flow rates was done from $50^{\text {th }}$ to $180^{\text {th }}$ day of lactation. Tests showed as expected better results among Holstein Friesian then Fleckvieh cows. The optimal distribution of milk flow rate of Holstein Friesian type was $56.58 \%$ and Fleckvieh was only $38.91 \%$. The results of the investigation are discussed. The milk flow rate represents an essential performance trait and should be included into the breeding program.
\end{abstract}

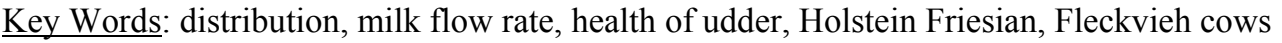

\section{Zusammenfassung}

Titel der Arbeit: Verteilung des Milchflusses bei Holstein Friesian und Fleckvieh Kühen in Kroatien

Das Ziel der Untersuchungen bestand im Vergleich der Milchflussraten und der Verteilung des Milchflusses von Holstein Friesian und Fleckvieh Kühen. Die Untersuchungen erfolgten an 435 Kühen aus vier Betrieben im Osten Kroatiens. Insgesamt wurden 2594 Messungen sowohl mit Hilfe einer Computer-Ausrüstung der Firma Alfa-Laval als auch mit Hilfe eines digitalen Milchflussmessgerätes der Firma Tru-Test zwischen dem 50. bis 180. Laktationstag durchgeführt. Die Holstein Friesian Kühe erreichten erwartungsgemäss bessere Ergebnisse als Fleckviehkühe. Die optimale Verteilung der Milchflussrate wurde für erstere mit 56,58 \% für Fleckvieh dagegen mit 38,91 \% gemessen. Die Ergebnisse der Untersuchungen werden diskutiert. Die Melkflussrate stellt ein wichtiges Leistungskriterium dar und sollte in das Zuchtprogramm aufgenommen werden.

Schlüsselwörter: Verteilung, Milchflussrate, Eutergesundheit, Holstein Friesian, Fleckvieh Kühe

\section{Introduction}

A good cow is a synonym for high milk productivity, health and resistance, as well as the rightly developed and functional udder. Until now, the selection of cows with high milk production caused decline in fertility and resistance against many diseases as well as mastitis which is the greatest cause of damage in milk production, both in health and economical sense (ROGERS, 1993; HARMON, 1994; DUDA, 1995; LUTTINEN and JUGA, 1997). Studying milk flow rate (MFR) and appliance of newer measure techniques we come to a greater number of cows adapted to machine milking and so reduce the number of udder sickens (GÖFT et al., 1994). Milking is possible to ameliorate through standardization of cow's udder and through the appliance of recent technologies. In this way (DODENHOFF and SPRENGL, 1999; DODENHOFF et al., 1999) and selection might build the most adequate udder for milking. Cows should be adapted to a man and the machines as well as machines should be adapted to the cows. To perform the most important milking parameters it is used: maximal milk flow rate (MMFR), average flow rate (AFR) and the milking time (MT) (POGAČAR, 1984; 
TREDE, 1987). Various speeds of AFR and MMFR, both, the slow ones and the fast, ones are able to cause health disorders of udder, in reference to, increased number of somatic cells (SC) (PERES-GUZMAN et al., 1986; BROWN et al., 1968; GRINDAL and HILLERTON, 1991; WORSTORFF and GÖFT, 1992; ROTH et al., 1998). Due to that this research wants to determine the temporary distribution of milk flow rate (MFR) on farms and to compare it with milk flow rate that has no influence on udder's health. We have compared all given results with all up today researches (BROWN et al., 1968; RÜGESEGGER, 1990; ALLMEN, 1994; ROTH et al., 1998; NAUMANN et al., 1998). This research wanted to present the possible improvements of methodology of cattle breed, as well as the eventual shortage of milking procedure. This could reduce the time labor in stables, increase milk production and its quality as well as health condition of udder.

\section{Material and Methods}

Regarding materials and methods, the tests were done on four different locations in Eastern Croatia (see Table 1). Two breeds were tested; Holstein Friesian as the representatives of milk breeds, and Fleckvieh breed as a representative of combined characteristics. The number of parameters in milking among Fleckvieh was 830, and among Holstein Friesian was 1764, which gives total of 2549 tests, in reference to, 1297 evening and 1297 morning milking. Total number of tested cows was 235 Fleckvieh and 303 Holstein Friesian. The milk yield of the examined populations is indicated in Table 2. The tests were done by the computer equipment made by AlfaLaval Company and with Tru-Flow digital counter of milk flow made by Tru-test Company. Cows had different lactations and were in correct morphological condition of udder and in general good health condition. All tested animals were registered at Croatian cattle selection Center.

Table 1

Characteristics of the investigated farms (Charakteristik der untersuchten Betriebe)

\begin{tabular}{ccccc}
\hline Farms & Cows (no.) & No. of measures & Keeping & Milking method \\
\hline 1 & & & & Milking parlour \\
2 & 323 & 2116 & Free rang keeping & Milk pipe \\
3 & 59 & 118 & Tying & Milk pipe \\
4 & 123 & 294 & Tying & Buckets \\
\hline
\end{tabular}

Table 2

Milk yield (kg) and standard deviation (s) of the examined populations (305 - day) (Milchertrag (kg) und Standardabweichungen (s) der untersuchten Population (305 - Tage))

\begin{tabular}{ccccc}
\hline Lactation & \multicolumn{3}{c}{ Fleckvieh } & \multicolumn{2}{c}{ Holstein Friesian } \\
\cline { 2 - 5 } & $\bar{x}$ & $\mathrm{~s}$ & $\bar{x}$ & $\mathrm{~s}$ \\
\hline 1 & 3896 & 514.2 & 5299 & 849.6 \\
2 & 4179 & 619.1 & 5942 & 910.7 \\
3 & 4302 & 633.0 & 6272 & 989.6 \\
$\geq 4$ & 4201 & 681.5 & 6210 & 1032.4 \\
\hline Average & 4109 & 646.7 & 5735 & 984.1 \\
\hline
\end{tabular}

The milk flow rate measuring was done from 50th to 180th day of lactation. The testing procedures of milk abilities were done according to the German Cattle Breeders Federation instructions (ADR, 1987). Parameter units have been measured to the point when the circulation of milk dropped under $0.2 \mathrm{~kg} / \mathrm{min}$. That was the milking time that 
was marked and used in further data processing. Measuring was done during morning and evening controls. Parameter units processed dates in a measuring unit $\mathrm{kg} / \mathrm{min}$. All milking devices were adjusted on the same values $(48-50 \mathrm{kPa})$, and pulsation rate of 60 cycles/min and a 2.5:1 (milking : rest) pulsation ratio.

The correction of MFR was made according to the NENADOVIC model (1978); POGAČAR (1984); JAKOPOVIĆ and KNEŽEVIĆ (1993), and was based on the regression coefficient between the amount of milked milk and the average uncorrected milk flow rate:

$\mathrm{CMFR}=\mathrm{AMFR}+\mathrm{b}_{\mathrm{XY}}(\mathrm{QM}-\bar{x})$

$\mathrm{CMFR}=$ corrected milk flow rate $(\mathrm{kg} / \mathrm{min})$,

AMFR $=$ absolute milk flow rate $(\mathrm{kg} / \mathrm{min})$,

$b_{\mathrm{XY}}=$ regression coefficient between average amount of milk and average uncorrected milk flow rate,

$\mathrm{QM}=$ quantity of milk in one milking $(\mathrm{kg})$

$\bar{x}=$ approximately constant calculated on the basis of the quantity of milk in standard milking procedure.

Statistic analyses of datas were done with program SAS, ver.6.03 (SAS INSTITUTE INC. 1988). Distributions of milk flow rate were defined (RÜGESEGGER, 1990, ALLMEN, 1994) in following classes: slow milk flow rate $($ SMFR $)=2.00$; optimal milk flow rate (OMFR) from 2.01 up to 3.60 , and fast milk flow rate $($ FMFR) $=3.61$ $\mathrm{kg} / \mathrm{min}$.

\section{Results}

Holstein Friesian cows from the first farm had an increase of MFR from the first to the third and the other lactations (Table 3). We have experienced similar results on the second farm as well, with an exception of the second lactation. The results of milk flow rate among Fleckvieh cows were interesting since MFR was faster during the second, but not in third and other lactations (Table 4). The cause is probably in the greater number of cows which were in late lactations (fifth and sixth) and whose milk production was lower than the cows in the second lactations.

Table 3

Means $(\bar{x})$ and standard deviations (s) for the average of corrected milk flow rate $(\mathrm{kg} / \mathrm{min})$ by lactations in Holstein Friesian cows (Mittelwerte $(\bar{x})$ und Standardabweichungen (s) für korrigierten durchschnittlichen Milchfluß von Holstein Friesian Kühen)

\begin{tabular}{|c|c|c|c|c|c|c|}
\hline \multirow[b]{2}{*}{ Farms } & \multicolumn{2}{|c|}{$\begin{array}{c}1 \\
\left(n^{*}=740\right)\end{array}$} & \multicolumn{2}{|c|}{$\begin{array}{c}2 \\
(n=252)\end{array}$} & \multicolumn{2}{|c|}{$\begin{array}{c}\geq 3 \\
(\mathrm{n}=772)\end{array}$} \\
\hline & $\bar{x}$ & $\mathrm{~S}$ & $\bar{x}$ & $\mathrm{~S}$ & $\bar{x}$ & $\mathrm{~S}$ \\
\hline 1 & 2.64 & 0.79 & 2.74 & 0.82 & 2.98 & 0.89 \\
\hline 2 & 1.65 & 0.45 & 1.51 & 0.27 & 1.82 & 0.34 \\
\hline
\end{tabular}

The highest percentage in total distribution of MFR for Holstein Friesian cows (Table 5) was optimal with the MFR: the first lactation was: $58.78 \%$, the second: $57.93 \%$, the third and the other: $60.63 \%$. The first and the second lactation had the lowest percentage of milk distribution with FMFR, and the third and the others, with SMFR. According to the adapted distribution in our research for all lactations, Holstein Friesian cows had more then a half distribution with OMFR. Fleckvieh cows had the 
highest distribution with SMFR. This class gave $87.50 \%$ milk distribution in the first lactation, and in the second, 57.29, the third 55.93 and further lactations. We expected the OMFR in all distributions and lactations, but in the first one we gained only $12.50 \%$, in the second $36.98 \%$, in the third and in the others $41.94 \%$.

Table 4

Means $(\bar{x})$ and standard deviations (s) for the average of corrected milk flow rate $(\mathrm{kg} / \mathrm{min})$ by lactations in Fleckvieh cows (Mittelwerte $(\bar{x})$ und Standardabweichungen (s) für korrigierten durchschnittlichen Milchfluß von Fleckvieh Kühen)

\begin{tabular}{|c|c|c|c|c|c|c|}
\hline \multirow[b]{2}{*}{ Farms } & \multicolumn{2}{|c|}{$\begin{array}{c}1 \\
(n=216)\end{array}$} & \multicolumn{2}{|c|}{$\begin{array}{c}2 \\
(n=192)\end{array}$} & \multicolumn{2}{|c|}{$\begin{array}{c}\geq 3 \\
(n=422)\end{array}$} \\
\hline & $\bar{x}$ & $\mathrm{~S}$ & $\bar{x}$ & $\mathrm{~S}$ & $\bar{x}$ & $\mathrm{~S}$ \\
\hline 1 & 1.78 & 0.53 & 2.27 & 0.87 & 2.14 & 0.65 \\
\hline 2 & 1.19 & 0.30 & 1.35 & 0.40 & 1.19 & 0.30 \\
\hline 3 & 1.29 & 0.33 & - & - & - & - \\
\hline 4 & 1.60 & 0.44 & 2.26 & 0.58 & 1.76 & 0.59 \\
\hline
\end{tabular}

Table 5

Distribution of corrected milk flow $(\mathrm{kg} / \mathrm{min})$ through lactation in Holstein Friesian and Fleckvieh cows (Verteilung des korrigierten Milchflusses $(\mathrm{kg} / \mathrm{min})$ durch die Lactation bei Holstein Friesian und Fleckvieh Kühen)

\begin{tabular}{ccrcrc}
\hline & & \multicolumn{2}{c}{$\begin{array}{c}\text { Holstein Friesian } \\
(\mathrm{n}=1764 \text { measurings })\end{array}$} & \multicolumn{2}{c}{$\begin{array}{c}\text { Fleckvieh } \\
(\mathrm{n}=830 \text { measurings })\end{array}$} \\
\hline Milk flow & Lactation & \multicolumn{1}{c}{$\mathrm{n}$} & $\%$ & $\mathrm{n}$ & $\%$ \\
\hline Slow & 1 & 219 & 29.60 & 189 & 87.50 \\
$\leq 2.00$ & 2 & 64 & 25.40 & 110 & 57.29 \\
& $\geq 3$ & 127 & 16.45 & 236 & 55.93 \\
\hline Total & & 410 & 23.24 & 535 & 64.46 \\
\hline Optimum & 1 & 435 & 58.78 & 27 & 12.50 \\
$2.01-3.60$ & 2 & 146 & 57.93 & 71 & 36.98 \\
& $\geq 3$ & 468 & 60.63 & 177 & 41.94 \\
\hline Total & & 1049 & 59.47 & 275 & 33.13 \\
\hline Fast & 1 & 86 & 11.62 & 0 & 0.00 \\
$\geq 3.61$ & 2 & 42 & 16.67 & 11 & 5.73 \\
& $\geq 3$ & 177 & 22.92 & 9 & 2.13 \\
\hline Total & & 305 & 17.29 & 20 & 2.41 \\
\hline
\end{tabular}

In total distribution for all lactations (Figure 1) Holstein Friesian cows had the greatest number of measurings in optimal limits of MFR (56.58\%). Minor part of the total distribution was with SMFR (21.03\%) and FMFR (22.39\%). The results among Fleckvieh cows (Figure 2) as the combined breed in Republic of Croatia had quite a different distribution. More than half of distribution (55.55\%) was within the limits of SMFR, and less in limit of FMFR (5.54\%). Most wanted, regarding to it, the OMFR had only $38.91 \%$ of distribution among Fleckvieh cows.

\section{Discussion}

To empty cow's udder, or to say, to start the milking process, it is necessary to have a stimulation which by activity of oxytocin makes the cow ready for milking. In all of this, the most significant factor is sucking canal which is in indirect connection with muscle function for closing the peak teats. The wideness of the canal and its closing ability make a very important barrier for successful defense from udder sickness (TREDE, 1987; BUTLER et al., 1992). Narrow or too wide sucking canal is one of the 


\begin{tabular}{|c|c|c|}
\hline Slow & Optimum & Fast \\
$(21.03 \%)$ & $(56.58 \%)$ & $(22.39 \%)$ \\
\hline
\end{tabular}

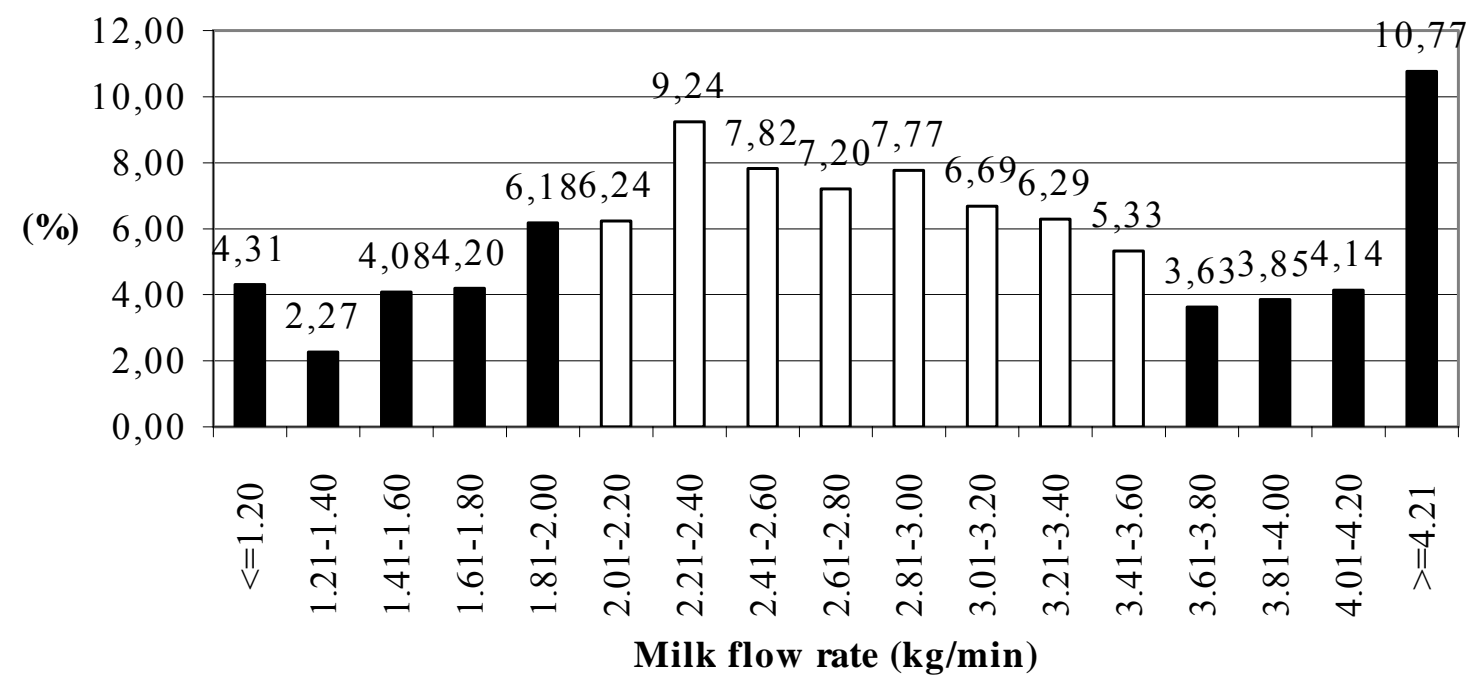

Fig. 1: Total distribution of corrected milk flow rate in Holstein Friesian cows ( $n=1764$ measurings) (Verteilung des korrigierten Milchflusses bei Holstein Friesian Kühen (n=1764 Messungen))

\begin{tabular}{|c|c|c|}
\hline Slow & Optimum & Fast \\
$(55.55 \%)$ & $(38.91 \%)$ & $(5.54 \%)$ \\
\hline
\end{tabular}

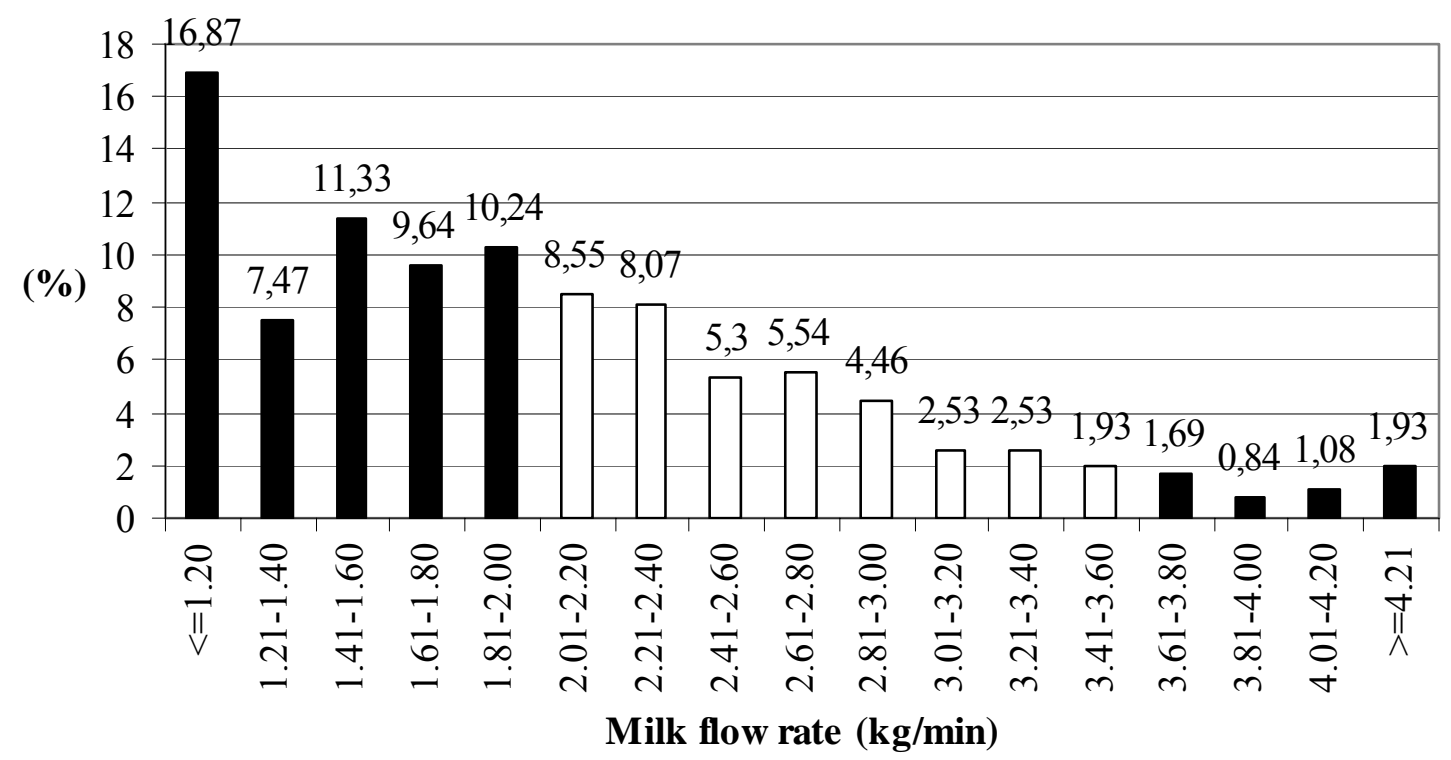

Fig. 2: Total distribution of corrected milk flow rate in Fleckvieh cows $(n=830$ measurings) (Verteilung des korrigierten Milchflusses bei Fleckvieh Kühen (n=830 Messungen))

factors which influences the speed of MFR. This physiological connection influence on the udder's health also. This supports the fact that diameter of sucking canal among easy milking cows, has central function of mechanical barrier against pathogenic 
germs penetration and infection. Phenotypic correlations between MFR rate and number of SC (BAHR et al., 1995a, 1995b) have demonstrated that number of SC grows with reduction of MT, regarding to, with rising the speed of MFR. Many health problems cause deviations in OMFR, but in technical and organizational problems during milking also, up to date results (PERES-GUZMAN et al., 1986; BROWN et al., 1986; GRINDAL and HILLERTON, 1991; ROTH et al., 1998) affirmed the theses that extreme speeds of the MFR (both, slow and fast) increasing degree of udder's infections. Dividing the MFR into certain speed limits, we could select and choose cows with extreme values of MFR. On the basis of calculation we found in our research (Table 5), we see that Holstein Friesian cows have more then a half percentage of milk distribution in all three lactations $(58.78 ; 57.93 ; 60.63 \%)$. In ultimate distribution of testing, they gave $59.46 \%$ of OMFR. Observing these results in Figure 1 we can see bimodal oscillation curve of slow and fast values (23.24 and 17.29\%). These results are not satisfactory suggested distribution (RÜGESEGGER, 1990; ALLMEN, 1994). Due to possibility of exposing to the udder infections in a large part of distribution. Researches made by PERES-GUZMAN et al. (1986) have demonstrated that the greatest minority of cows infected by mastitis had OMFR between 1.6 and $2.6 \mathrm{~kg} / \mathrm{min}$. All values under and above contained larger number of pathogenic germs in milked milk. Similar results had other authors which just approved previous researches. In this way ROTH et al. (1998) have found that the most number of cows with germs diagnosis in milk were those who had lower milk flow rate, lower than 2.0 and higher than $4.0 \mathrm{~kg} / \mathrm{min}$. Our tests done on Fleckvieh cows have presented larger distribution with SMFR than OMFR. The same conclusion is valid for total distribution of the CMFR (Figure 2). Even $55.55 \%$ of total distribution had SMFR, and only $38.91 \%$ had FMFR. The results (RÜGESEGGER, 1990; ALLMEN, 1994) present that 82.6, better to say, 86.0\% of Fleckvieh cows had OMFR. On the basis of these facts, it is clear that Fleckvieh cows have unequal milk flow rate.

In improvement of present condition of cattle breed in Croatia, our research results has shown that milking abilities should become one of our selective goals. According to this, the most important milking parameters would be MFR and MT. These parameters, adjusted with udder's health, scientifically will reduce mastitis among cows and save great sums of money. Republic Croatia which, at this moment, produce insufficiently, is a bit over a half quantity of milk. This production has a promising future, but it has to develop its breeding program. Milking farms urgently need to change old and out of date equipment and technologies for they can achieve continuous production and quality of milk only if they apply these factors. Then the milk production will be adequate and sufficient for whole country, and the rest would be possible to sell on the European and world's market.

\section{References}

ALLMEN, M.:

Bericht über die Ergebnisse der Melkbarkeitsprüfungen beim Schweizer Fleckvieh. Schweizer Fleckvieh, 7 (1994), 86-93

ARBEITSGEMEINSCHAFT DEUTSCHER RINDERZÜCHTER, ADR:

Empfehlung 3.3 für die Durchführung von Melkbarkeitsprüfungen. Bonn, RL 3.3, Stand 4 (1987), 3.13.3 
BAHR, T.; PREISINGER, R.; KALM, E.:

Untersuchungen zur Zellzahl und Melkbarkeit beim Rind. 1. Mitteilung: Schätzung genetischer Parameter für die Zellzahl. Züchtungskunde 67 (1995 a), 91-104

BAHR, T.; PREISINGER, R.; KALM, E.: Untersuchungen zur Zellzahl und Melkbarkeit beim Rind. 2. Mitteilung: Genetische Parameter der Melkbarkeit. Züchtungskunde 67 (1995 b), 105-116

BROWN, C. A.; RISCHETT, S. J.; SCHULTZ, L. H.:

Relationship of Milking Rate to Somatic Cell Count. J. Dairy Sci. 69 (1986), 850-854

BUTLER, M. C.; HILLERTON, J. E.; GRINDAL, R. J.:

The Control of Milk Flow Through the Teats of Dairy Cows. J. Dairy Sci. 75 (1992), 1019-1024

DODENHOFF, J.; SPRENGEL, D.; DUDA, J.; DEMPFLE, L:

Potential Use of Parameters of the Milk Flow Curve for Genetic Evaluation of Milkability. In: Proceedings Internat. Workshop Genetic Improvement of Functional Traits in Cattle. Bulletin No. 23. International Committee Animal Recording, Uppsala, Sweden (1999), 131-141

DODENHOFF, J.; SPRENGEL, D.:

DUDA, J. Perspektiven der Zuchtwertschätzung für Melkbarkeit. BLT Grub (1999), 1-3

Beziehungen zwischen Melkbarkeit und Mastitisanfälligkeit. Züchtungskunde 67 (1995), 467-476

GÖFT, H.; DUDA, J.; DETHLEFSEN, A.; WORSTORFF, H.:

Untersuchungen zur züchterischen Verwendung der Melkbarkeit beim Rind unter Berücksichtigung von Milchflußkurven. Züchtungskunde 66 (1994), 23-37

GRINDAL, R. J.; HILLERTON, J. E.:

Influence of milk flow rate on new intramammary infection in dairy cows. J. Dairy Res 58 (1991), 263268

HARMON, R. J.:

Physiolgy of Mastitis and Factors Affecting Somatic Cell Counts. J. Dairy Sci. 77 (1994), 2103-2112

JAKOPOVIĆ, I.; KNEŽEVIĆ, I.:

Upute za provođenje testa muznosti. Hrvatski stočarski selekcijski centar, Zagreb, (1993), 1-4

LUTTINEN, A.; JUGA, J.:

Genetic relationships between milk yield, somatic cell count, mastitis, milkability and leakage in Finnish dairy cattle populations. Proceedings International Workshop on Genetic Improvement of Functional Traits in cattle (GIFT) - Health. Uppsala. INTERBULL Bulletin 15 (1997), 78-83

NAUMANN, I.; FAHR, R.D.; LENGERKEN, G. v.:

Zusammenhang zwischen dem Gehalt an somatischen Zellen in der Milch und ausgewählten Parametern der Milchflußkurve bei Kühen. Arch. Tierz., Dummerstorf 41 (1998) 3, 237-250

NENADOVIĆ, M.:

Primena različitih postupaka za eliminisanje uticaja količine mleka na brzinu muže. Stočarstvo, 32 (1978), 37-43

PERES-GUZMAN, M. D.; CLAUS, J.; JUNGE, W.; KALM, E.:

Untersuchungen zur Melkbarkeit und Eutergesundheit beim Rind. 2. Mitteilung: Analyse der Daten aus der offiziellen Melkbarkeitsprüfung in Schleswig-Holstein. Züchtungskunde 58 (1986), 75-86

POGAČAR, J.:

Kontrola in selekcija v govedoreji. "Kmečki glas", Ljubljana. Knjižnica za pospešavanje kmetijstva, (1984), XV/1985

ROGERS, G. W.:

Index Selection Using Milk Yield, Somatic Cell Score, Udder Depth, Teat Placement, and Foot Angle. J. Dairy Sci. 76 (1993), 664-670

ROTH, S.; REINSCH, N.; NIELAND, G.; SCHALLENBERGER, E.

Untersuchungen über Zusammenhänge zwischen Eutergesundheit, Melkbarkeitsparametern und Milchflußkurven an einer Hochleistungsrinderherde. Züchtungskunde 70 (1998), 242-260

RÜGESEGGER, A.:

Bericht über die Ergebnisse der Melkbarkeitsprüfungen beim Simmentaler Fleckvieh. Simmentaler Fleckvieh 7 (1990), 74-81

SAS INSTITUTE INC.:

TREDE, J.:

SAS/STAT User's Guide Release 6.03 Edition (1988), Cary, NC, USA

Genetische Analyse der Parameter der Eutergesundheit und der Melkbarkeit. Diss., Schriftenreihe des Institutes für Tierzucht und Tierhaltung der Christian-Albrechts-Universität zu Kiel, (1987), Heft 44

WORSTORFF, H.; GÖFT, H.:

Milchflussgesteuertes Melken: Möglichkeiten und Grenzen. Landtechnik 12 (1992) 625-627 
Received: 2001-10-16

Accepted: 2002-06-05

Author's address

Prof. Dr. IVAN KNEŽEVIĆ, Doc. Dr. MATIJA DOMAĆINOVIĆ, M. Sc. PERO MIJIĆ, M. Sc. MIRJANA BABAN, M. Sc. DAVOR KRALIK

University of J. J. Strossmayer in Osijek

Faculty of Agriculture

Trg sv. Trojstva 3

CRO-31000 Osijek

E-Mail: pmijic@suncokret.pfos.hr 